\title{
Assessment of Groundwater Resources in a Complex Volcanic Reservoir with Limited Data Sets in a Semi-Arid Context Using a Novel Stochastic Approach. The Goda Volcanic Massif, Republic of Djibouti
}

\author{
Ibrahim M. Ahmed1,2, Mathieu Le Coz¹, Mohamed Jalludin'², Paul Sardini1, Moumtaz Razack ${ }^{*}$ \\ ${ }^{1}$ University of Poitiers, Poitiers, France \\ ${ }^{2}$ Centre d'Études et de Recherches de Djibouti (CERD), Djibouti, Republic of Djibouti \\ Email: *moumtaz.razack@univ-poitiers.fr
}

How to cite this paper: Ahmed, I.M., Le Coz, M., Jalludin, M., Sardini, P. and Razack, M. (2018) Assessment of Groundwater Resources in a Complex Volcanic Reservoir with Limited Data Sets in a Semi-Arid Context Using a Novel Stochastic Approach. The Goda Volcanic Massif, Republic of Djibouti. Journal of Water Resource and Protection, 10, 106-120. https://doi.org/10.4236/jwarp.2018.101007

Received: October 23, 2017

Accepted: January 28, 2018

Published: January 31, 2018

Copyright (c) 2018 by authors and Scientific Research Publishing Inc. This work is licensed under the Creative Commons Attribution International License (CC BY 4.0).

http://creativecommons.org/licenses/by/4.0/

\section{cc) (i) Open Access}

\begin{abstract}
This work focuses on the modeling and evaluation of water resources in complex aquifer systems and the use of scarce data. The modeling work is developed based on the GLUE (Generalized Likelihood Uncertainty Estimation) method. This method is still little used in hydrogeology, although its applications in other disciplines such as hydrology proved quite efficient. The study site, located in the Republic of Djibouti (Horn of Africa), is represented by the volcanic massif of Goda. The hydraulic properties of this massif are highly heterogeneous since they are associated with fracturing and weathering of the geological formations. The data are too few to enable a conventional modeling approach of this volcanic system. The implementation of the GLUE method in a numerical groundwater flow model allowed developing a stochastic analysis of the spatial distribution of the hydraulic conductivity and the recharge modalities of this complex volcanic system. The hydraulic conductivities range from $10^{-6}$ to $10^{-8} \mathrm{~m} \cdot \mathrm{s}^{-1}$ for the basalt and the rhyolite formations (values are yet generally lower for rhyolites) and are higher than $5 \times 10^{-7}$ for the sedimentary formations. In addition, considering diffuse recharge as the main mechanism by which the precipitation reaches the aquifer results in more consistent groundwater head simulations than considering only indirect recharge. The average recharge amount estimated for the Goda aquifer system is $28 \mathrm{~mm} \cdot \mathrm{yr}^{-1}$. The results led to a numerical representation of this system, with the least uncertainty. This model was able to estimate the available water resources of this system. This result is important because the Goda system sup-
\end{abstract}


plies water to the city of Tadjourah. Assessment of available resources is vital for the future development of this city. From a methodological point of view, the GLUE method proved very promising for water resources assessment in complex hydrogeological systems for which little data are available.

\section{Keywords}

Water Resources, Stochastic Modeling, GLUE, Volcanic Systems, Goda Aquifer, Djibouti

\section{Introduction}

Understanding the hydrodynamic functioning of volcanic aquifer systems is confronted with the difficulty of dealing with their geometrical complexity and the high spatial heterogeneity of the recharge processes and flow parameters distributions [1] [2] [3] [4]. Volcanic aquifers have been studied quite extensively in developed countries [5] [6], but few studies have been undertaken in developing countries [7], where they are very often the only available water resources [8] [9].

Given their strong heterogeneity, studying these hydrogeological systems require a high density and quality of data, which explains why such studies have been mainly carried out for systems equipped with well-developed monitoring networks. Volcanic aquifers for which access to data (in time and space) is limited are generally poorly described whereas they can be a crucial resource, especially in arid environments. The lack of data constitutes a real difficulty in assessing the resources of these aquifers [10] [11].

More particularly, optimization procedures, which consist in minimizing the differences between simulated and observed loads, generally implemented in order to identify the parameters of the hydrodynamic models lead in some cases to the instability or non-uniqueness of the solution [12] [13] [14] [15] [16]. Strategies to better account for uncertainties should thus be implemented such as the GLUE (Generalized Likelihood Uncertainty Estimation) method [17]. This stochastic method consists in testing a large number of parameter sets and keeping all those which allow to simulate the observed hydraulic heads taking account of their uncertainties.

The GLUE procedure is quite recent and has been very little applied in Hydrogeology [18] [19] [20] [21]. However, this procedure would offer very interesting perspectives when aquifers are very complex with very little data available. This situation is frequently encountered in developing countries concerning volcanic aquifers. Under these circumstances, the little data available does not permit to conduct a classical and effective modeling of these systems. Yet modeling these systems is imperative, since they represent the only resources available, which must necessarily be exploited within a sustainable framework. 


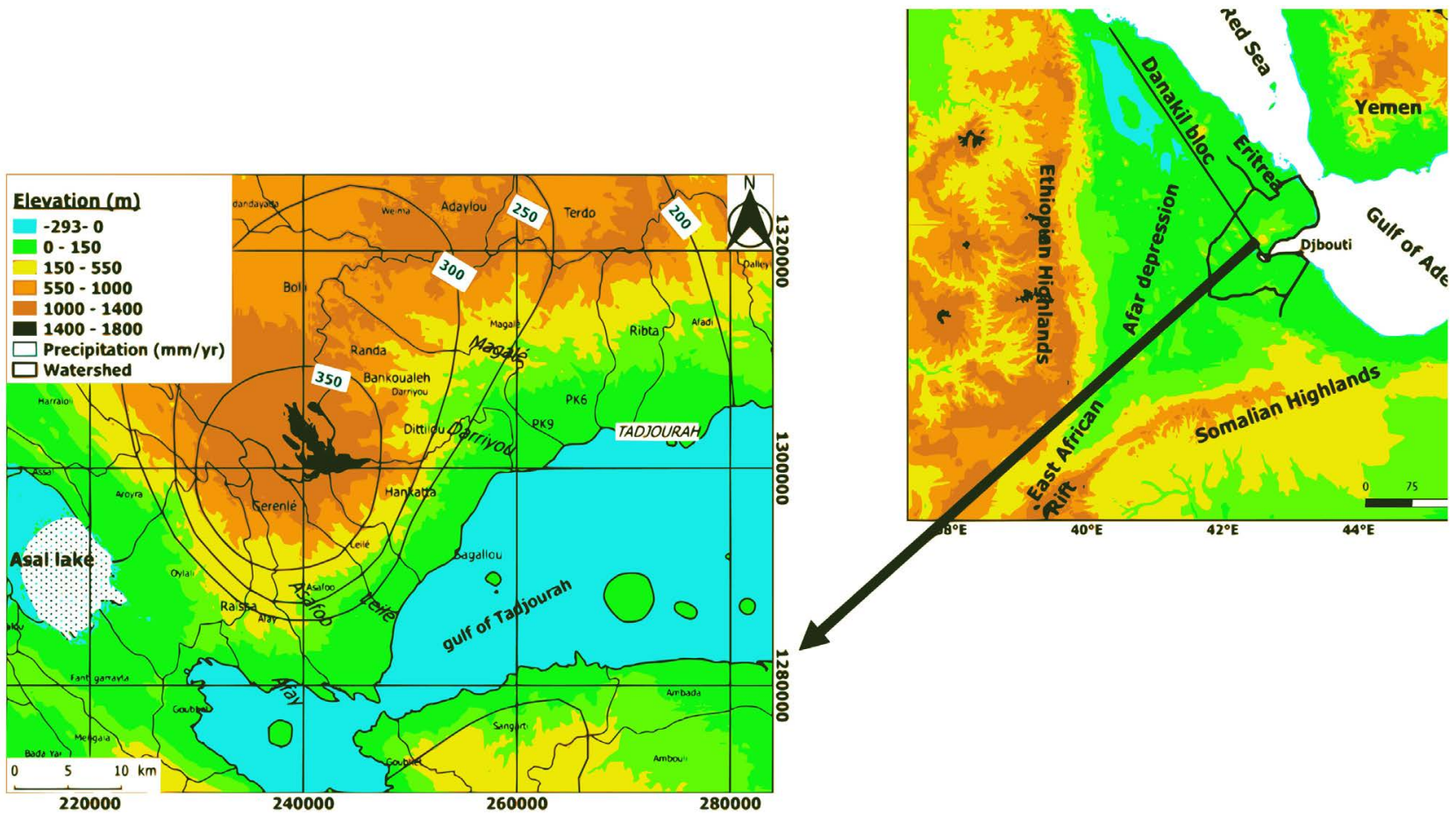

In this work, the GLUE approach was applied to the modeling of the Goda volcanic aquifer in the Republic of Djibouti (Horn of Africa).

\section{The Study Area}

\subsection{Geomorphological Features}

The Goda massif (Figure 1) is located to the west of the city of Tadjourah. This steep area consists of hills and narrow valleys. It is bordered to the south-east by the littoral and is limited to the north by the plateau of Dalha at the village of Adaylou. On the northern and western slopes of Day Mountain, which peaks at $1800 \mathrm{~m}$, the altitude of the massif decreases steadily. The massif is limited to the south and west by Lake Assal $(-150 \mathrm{~m}$ asl) and the fault zone of Makarassou. The central slope of the massif is home to Day's primary forest and consists of three exoreic watersheds (Darriyou, Magalé, Asleyi). The relief is particularly steep with dips reaching more than $35^{\circ}$ on the descent of Day Mountain.

Precipitations over the massif of Goda are higher than the average over the territory of Djibouti (150 mm/year). Indeed, more than $350 \mathrm{~mm} /$ year of rainfall are recorded on the high zones. The precipitation decreases until reaching 200 $\mathrm{mm} /$ year on the coast near the city of Tadjourah (Figure 1 ).

\subsection{Geology}

The Goda massif is located on the terminal part of the Danakil block bounded to the north in Eritrea by Precambrian sedimentary rocks [22] [23]. The tectono-volcanic activities following the opening of the Red Sea [24] [25] [26] set up

Figure 1. Location of the Goda massif. 
the volcanic rocks of the Goda massif. The oldest geological unit is the formation of the Mabla rhyolites dating of the Miocene [27]. This unit outcrops on the central and northern part of the massif. Normal faults of N160 or N50 direction intersect the series of Mabla rhyolites.

The Mabla rhyolites are covered to the west by Dalha basalts (4 - $9 \mathrm{Ma})$ and stratoid basalts (1.25 - 3.5 My) [28]. Dalha basalts are weakly faulted and subhorizontal whereas the stratoid basalt series is affected by normal N-S main faults. There are some outcrops of the Gulf basalts (1.25 - 3 My), of the Asal series basalts [29] and of the Mabla basalts, which are a contemporary series of the Mabla rhyolites. Sedimentary formations ( $<2 \mathrm{My}$ ), composed of detrital materials, are mainly located on the coast, but can also be intercalated in volcanic formations (Figure 2).

The aquifer system of the Goda massif is defined by three hydrogeological units consisting of Dalha basalts, Mabla rhyolites and sedimentary formations. On the top of the massif, in the village of Day, two boreholes drilled until depths of 323 and $358 \mathrm{~m}$ allowed to estimate their thickness (locally) to $300 \mathrm{~m}$. The total thickness of the Mablas rhyolite is not known. Electric soundings performed at the mouths of the Darriyou and Magalé rivers have shown that the total thickness of the sediments could exceed $300 \mathrm{~m}$.

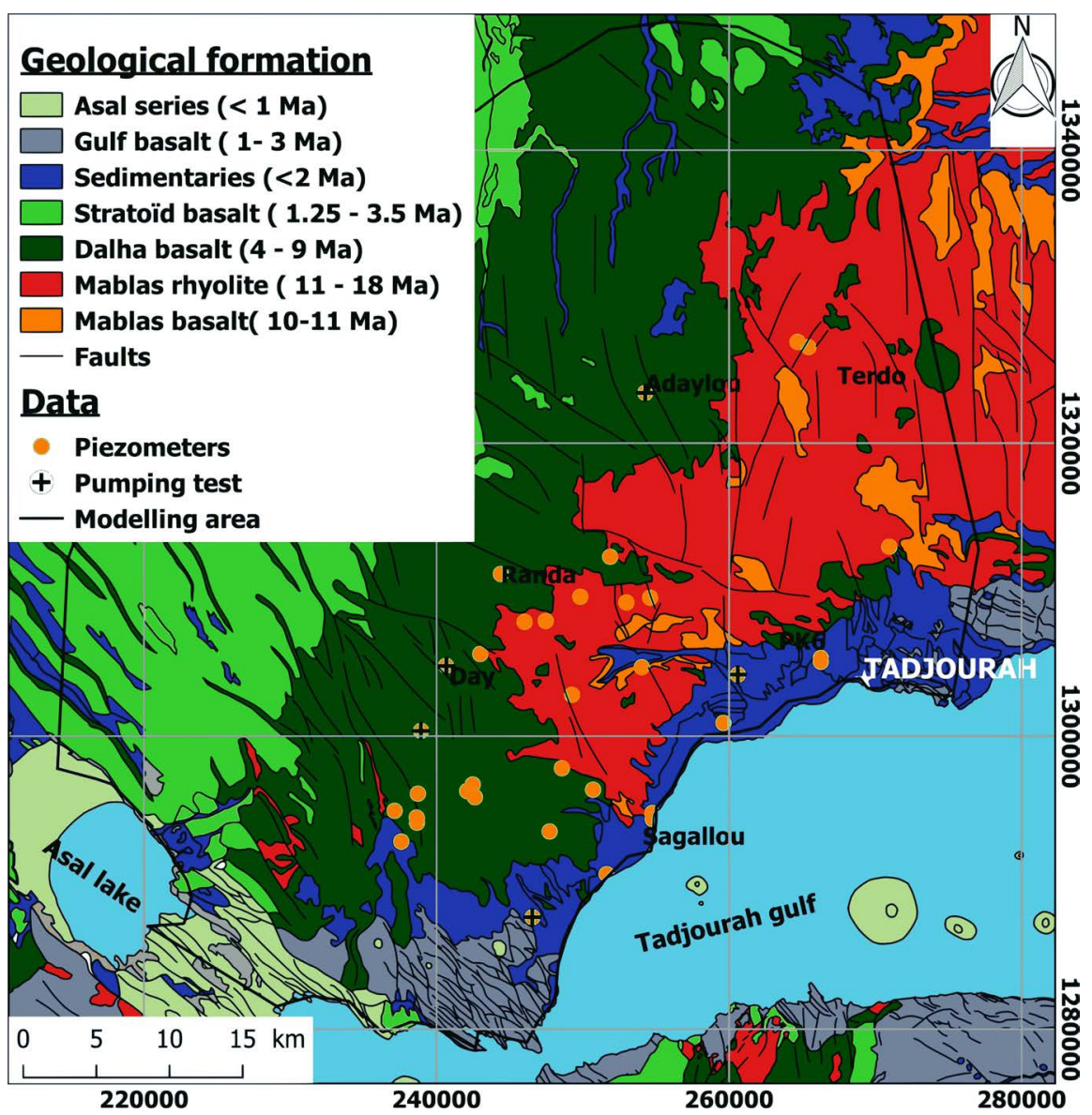

Figure 2. Geological context of the Goda massif. 


\subsection{Data}

Over the whole Goda massif, 38 water points are available with piezometric data. They include 19 wells, 10 boreholes and 9 springs (Table 1). Pumping tests were carried out on only 5 boreholes, 4 of which are located in the Dalha basalts and only one in the sedimentary formations (Table 2). The water points are not evenly distributed over the study area. They are mainly concentrated in the central part of the massif and along the coast.

\section{Methodological Approach}

In order to evaluate the dominant recharge processes in the south-eastern slope of the Goda massif, a numerical modeling of the groundwater flow was implemented by considering two distinct scenarios: i) a diffuse recharge over the entire zone; and ii) an indirect recharge from the rivers beds. The MODFLOWUSG code [30] was used to solve the equations governing underground flows.

\subsection{Geometry of the Volcanic System and Boundary Conditions}

The Goda aquifer system is conceptualized with two layers: i) a top layer corresponding to a relatively productive zone with a thickness of $300 \mathrm{~m}$; and ii) a semi-permeable lower layer that corresponds to a relatively unproductive zone in relation with the progressive clogging of deep fractures with a thickness of $1000 \mathrm{~m}$. The top of the upper layer is defined by the DEM (Figure 1).

The model domain is limited to the south-east by the coastline where a fixed head of $0 \mathrm{~m}$ is set, to the south-west by Lake Assal where a fixed head of $-150 \mathrm{~m}$ is set; to the northwest by a head contour line of $800 \mathrm{~m}, 30 \mathrm{~km}$ northwest from the summit of the Goda, where a fixed head of $800 \mathrm{~m}$ is set.

The area of the domain is $1800 \mathrm{~km}^{2}$ and a regular discretization with a mesh size of $500 \mathrm{~m} \times 500 \mathrm{~m}$ (11,600 mesh) has been considered. The boundary conditions are shown in Figure 3.

\subsection{Hydraulics Parameters}

A constant hydraulic conductivity $(\mathrm{K})$ of $10^{-8} \mathrm{~m} \cdot \mathrm{s}^{-1}$ is assigned to the lower layer, considered to be semi-permeable. Lower values of $\mathrm{K}$ do not significantly modify the simulated heads, but increase the calculation times. For the upper layer, three zones of hydraulic conductivity are defined on the basis of the geological map (basalts, rhyolites and sedimentary formations) (Figure 4).

In the first modeling scenario, a diffuse recharge is considered according to three zones defined on the basis of the isohyets $\left(>350 \mathrm{~mm} \cdot \mathrm{y}^{-1} ; 250\right.$ to 350 $\mathrm{mm} \cdot \mathrm{y}^{-1} ;>250 \mathrm{~mm} \cdot \mathrm{y}^{-1}$ ) (Figure 5). In the second scenario, recharge is applied only to the model cells corresponding to the drainage network. The three zones defined based on the isohyets are associated with different degrees of the network development and with distinct indirect recharge values (Figure 6). To prevent the accumulation of water above the topographic surface, mesh drainage at the level of the DEM is carried out where necessary. 
Table 1. Inventory of water points in the study area.

\begin{tabular}{|c|c|c|c|}
\hline Name & $\mathrm{X}(\mathrm{m})$ & $\mathrm{Y}(\mathrm{m})$ & measured head (m asl) (m) \\
\hline Marra & 237,139 & $1,294,905$ & 866.4 \\
\hline Ideyta & 237,589 & $1,292,805$ & 680.5 \\
\hline Stowele & 238,639 & $1,294,455$ & 893.1 \\
\hline Towele1 & 238,669 & $1,294,095$ & 823.4 \\
\hline Towele2 & 238,669 & $1,294,395$ & 858.6 \\
\hline Gerenle2 & 238,699 & $1,296,075$ & 1070.3 \\
\hline Gerenle1 & 238,729 & $1,296,075$ & 1072.6 \\
\hline Itki & 238,939 & $1,300,365$ & 1330.9 \\
\hline Day & 240,650 & $1,304,805$ & 1295.1 \\
\hline Boli & 240,740 & $1,316,865$ & 819.7 \\
\hline souboulta & 242,090 & $1,296,255$ & 954.6 \\
\hline Aleili & 242,480 & $1,296,705$ & 992.1 \\
\hline Illalou & 242,630 & $1,295,835$ & 886.7 \\
\hline Madagle & 242,990 & $1,305,615$ & 1217.2 \\
\hline Randa & 244,400 & $1,311,075$ & 970.5 \\
\hline Sankoualeh & 246,020 & $1,307,805$ & 721.9 \\
\hline Nghoubet & 246,560 & $1,287,645$ & 0.5 \\
\hline Ounda_ela & 247,460 & $1,307,865$ & 631.7 \\
\hline Wea & 247,730 & $1,293,495$ & 371.6 \\
\hline weer & 248,570 & $1,297,815$ & 610.5 \\
\hline Douda & 249,260 & $1,302,825$ & 608.8 \\
\hline Amiso & 249,831 & $1,309,515$ & 588.2 \\
\hline Hankata & 250,701 & $1,296,345$ & 296.8 \\
\hline Akabarta & 251,631 & $1,290,585$ & 0.4 \\
\hline Garassou & 251,871 & $1,312,245$ & 694.5 \\
\hline Akaabar & 252,981 & $1,309,125$ & 480.2 \\
\hline Dougoum & 254,031 & $1,304,715$ & 325.0 \\
\hline Adaylou & 254,271 & $1,323,435$ & 970.5 \\
\hline Affaloyna & 254,601 & $1,309,455$ & 441.6 \\
\hline Douloul2 & 254,751 & $1,294,755$ & 4.7 \\
\hline Douloul1 & 254,781 & $1,294,335$ & 3.1 \\
\hline Kalaf & 259,612 & $1,300,905$ & 0.4 \\
\hline PK9 & 260,602 & $1,304,205$ & 5.0 \\
\hline Oukwalou & 264,682 & $1,326,915$ & 828.7 \\
\hline Ayri & 265,432 & $1,326,555$ & 852.6 \\
\hline PK6-7 & 266,272 & $1,305,345$ & 7.7 \\
\hline PK6-6 & 266,272 & $1,305,075$ & 4.9 \\
\hline Daimoli & 270,953 & $1,312,935$ & 376.1 \\
\hline
\end{tabular}


Table 2. Transmissivity values derived from pumping tests.

\begin{tabular}{clc}
\hline Name & Aquifer & $\mathrm{T}\left(\mathrm{m}^{2} / \mathrm{s}\right)$ \\
\hline Adaylou & Dalha basalts & $2.04 \times 10^{-4}$ \\
Day & Dalha basalts & $8.15 \times 10^{-3}$ \\
Itki & Dalha basalts & $3.23 \times 10^{-4}$ \\
Bolli & Dalha basalts & $2.96 \times 10^{-6}$ \\
Nghoubet & Dalha basalts & $4.07 \times 10^{-3}$ \\
PK9 & Sedimentary & $6.95 \times 10^{-4}$
\end{tabular}

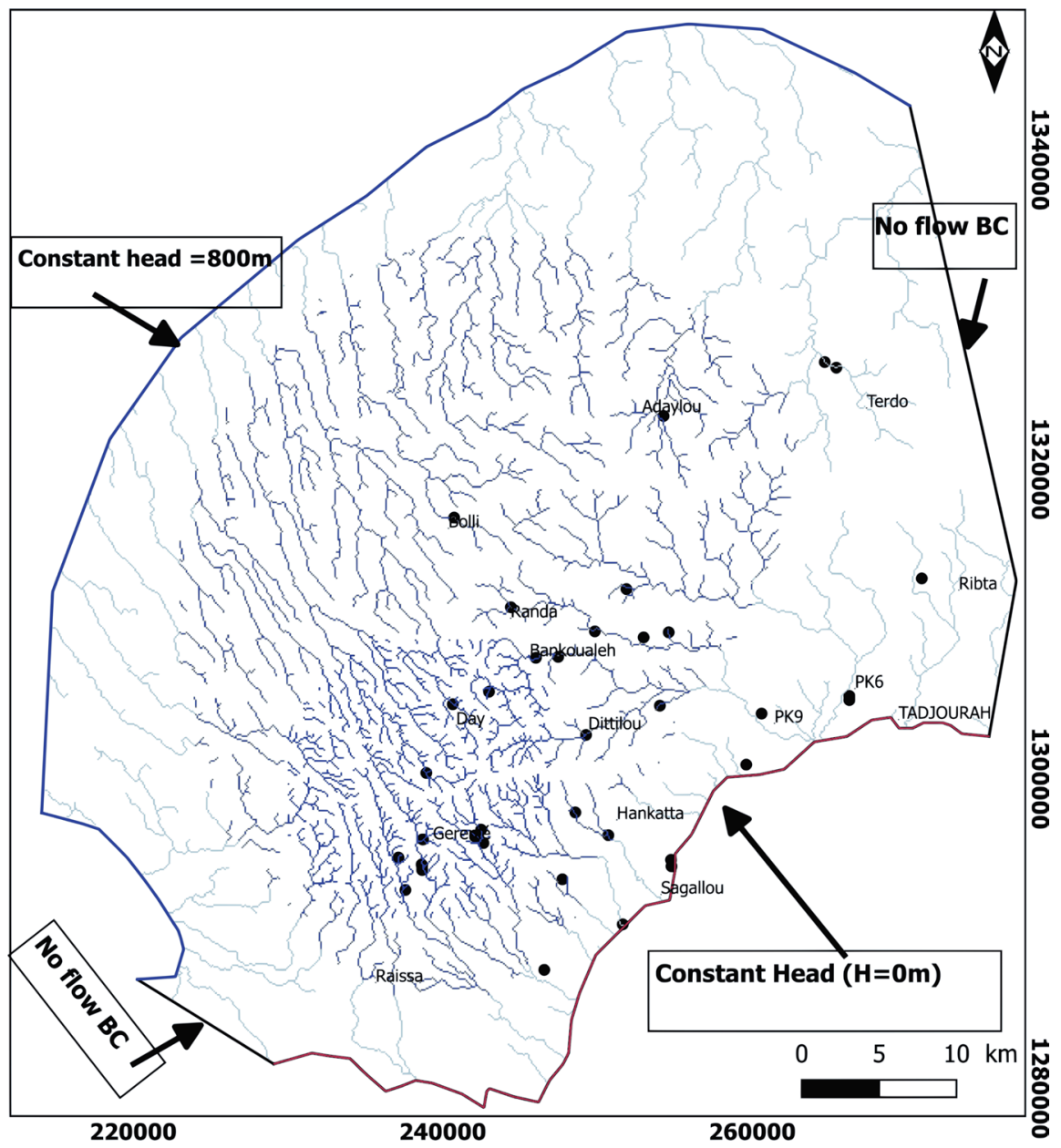

Figure 3. Boundary conditions of the model domain.

\subsection{Identification of Parameters}

To identify the values of both hydraulic conductivity and recharge on the different zones defined above, a GLUE (Generalized Likelihood Uncertainty Estimation) approach is implemented. This method considers that several sets of input parameters can result in a concordance between the simulated and observed values of a given variable. The strategies adopted are the following:

1) 10,000 sets of parameters (hydraulic conductivities ranged from $10^{-4}$ to $10^{-8}$ $\mathrm{m} \cdot \mathrm{s}^{-1}$ and recharges ranged from 0 to $400 \mathrm{~mm} \cdot \mathrm{y}^{-1}$ for each of the different zones 


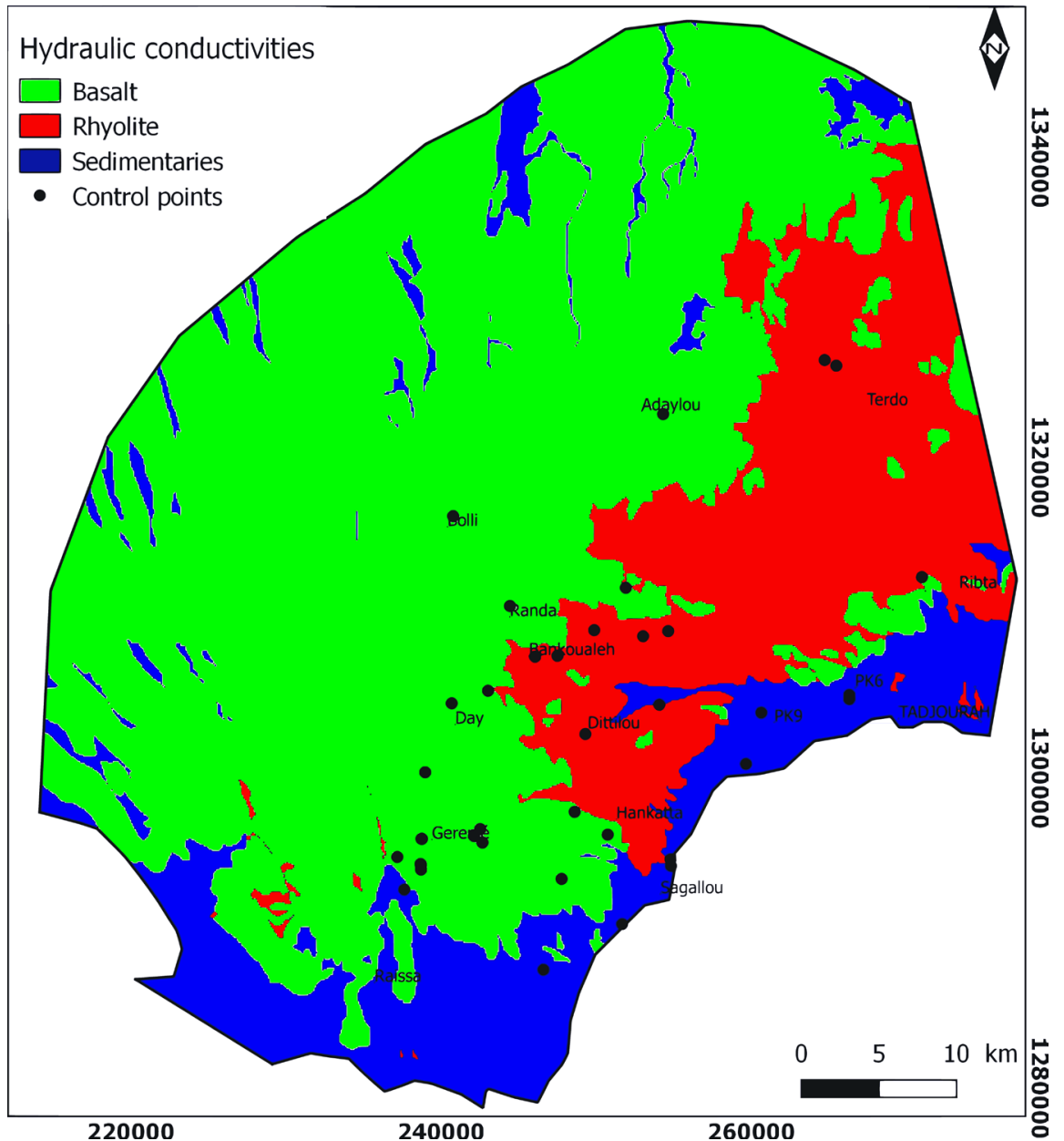

Figure 4. Hydraulic conductivity $\left(\mathrm{K}, \mathrm{m} \cdot \mathrm{s}^{-1}\right)$ distribution.

defined in Section (3.2) are generated randomly according to a Uniform distribution;

2) a model performance indicator is defined, based on the Root Mean Square Error (RMSE) between the measured and simulated hydraulic heads on the 39 control wells;

3) 10,000 simulations (with each of the parameter sets) are run and the 250 sets of parameters resulting in the lowest RMSEs are kept to establish probability densities.

\section{Results}

\subsection{Scenario 1: Modeling with Diffuse Recharge}

The differences between observed and simulated heads for the 250 selected simulations vary significantly according to the control wells. These differences must be compared with the uncertainty in the topography, in particular due to the change in DEM resolution from $30 \mathrm{~m}$ to $500 \mathrm{~m}$ in modeling. Indeed, in zones with high vertical differences, this uncertainty reaches $\pm 100 \mathrm{~m}$ (Figure 7). The probability densities obtained for $\mathrm{K}$ indicate that volcanic formations are 


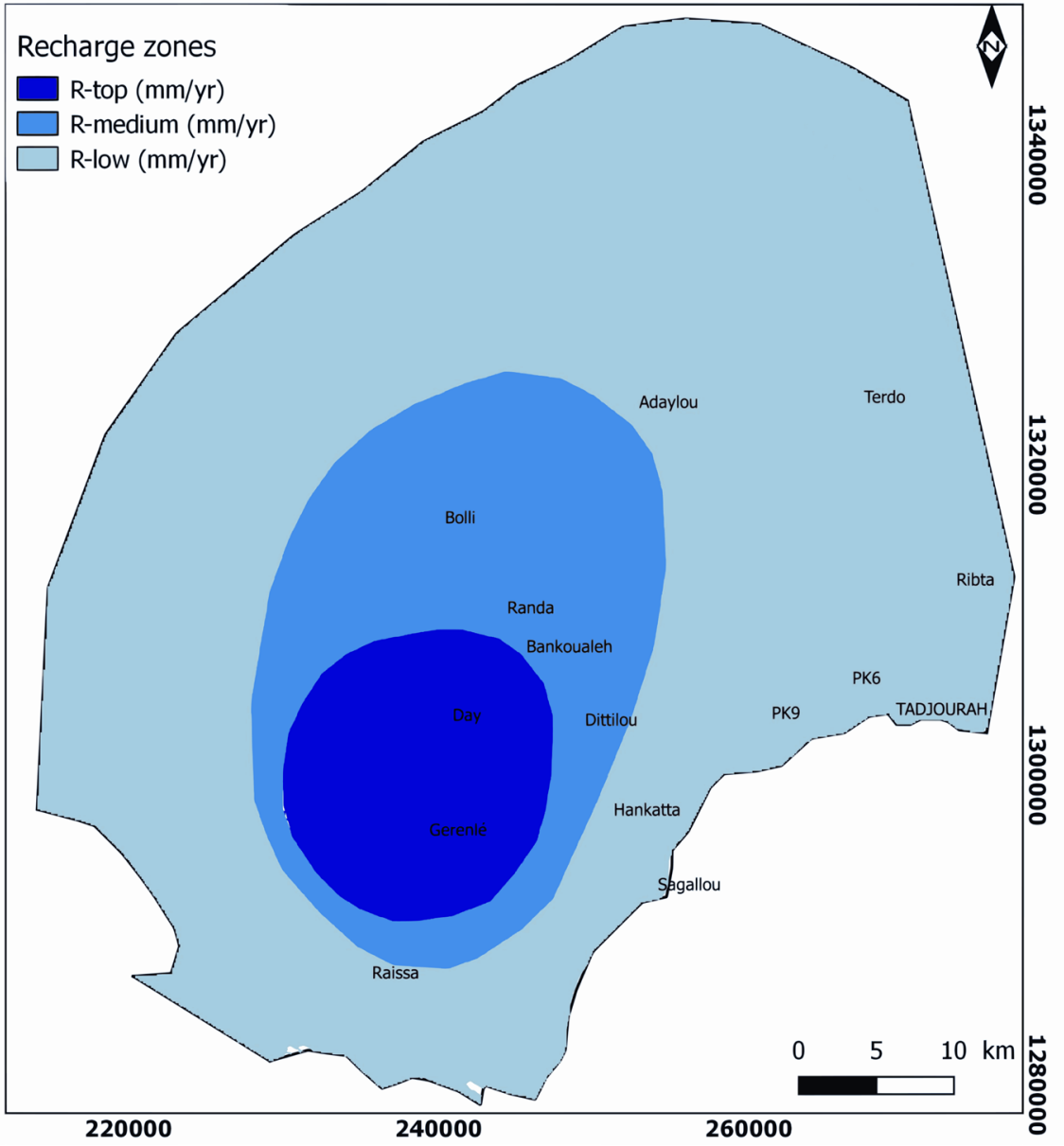

Figure 5. Recharge zones for the first scenario (Diffuse recharge).

less permeable than sedimentary formations. The $\mathrm{K}$ values obtained for the Dalha basalts range from $10^{-8} \mathrm{~m} \cdot \mathrm{s}^{-1}$ to $10^{-6} \mathrm{~m} \cdot \mathrm{s}^{-1}$ with a modal value of $10^{-7} \mathrm{~m} \cdot \mathrm{s}^{-1}$. The $\mathrm{K}$ values obtained for Mabla rhyolites are generally lower, with a modal value of $10^{-8} \mathrm{~m} \cdot \mathrm{s}^{-1}$. The $\mathrm{K}$ values obtained for sedimentary formations are higher than $5 \times 10^{-7} \mathrm{~m} \cdot \mathrm{s}^{-1}$ and two modal values are distinguished, $10^{-6}$ and $5 \times 10^{-4}$ $\mathrm{m} \cdot \mathrm{s}^{-1}$ (Figure 8 ). The probability densities obtained for the diffuse recharge indicate that this parameter is lower for the upper zone (values ranged from 10 to $30 \mathrm{~mm} \cdot \mathrm{y}^{-1}$; modal value of $20 \mathrm{~mm} \cdot \mathrm{y}^{-1}$ ) than for the middle zone (values higher than $20 \mathrm{~mm} \cdot \mathrm{y}^{-1}$; modal value of $40 \mathrm{~mm} \cdot \mathrm{y}^{-1}$ ). For the low zone, not any clear trend can be identified (Figure 9).

\subsection{Scenario 2: Modeling with Indirect Recharge}

Overall, the same trend as in the first scenario is observed for the second scenario, but on average the hydraulic conductivity values are slightly lower than the previous ones. Indeed, values between 3.4 and $8.5 \times 10^{-8} \mathrm{~m} \cdot \mathrm{s}^{-1}$ for volcanic formations and a value of $3.4 \times 10^{-6} \mathrm{~m} \cdot \mathrm{s}^{-1}$ for sedimentary formations are obtained (Figure 10). For this configuration, since the recharge is assigned only to the drainage network, the values required to adjust simulation and observation are 


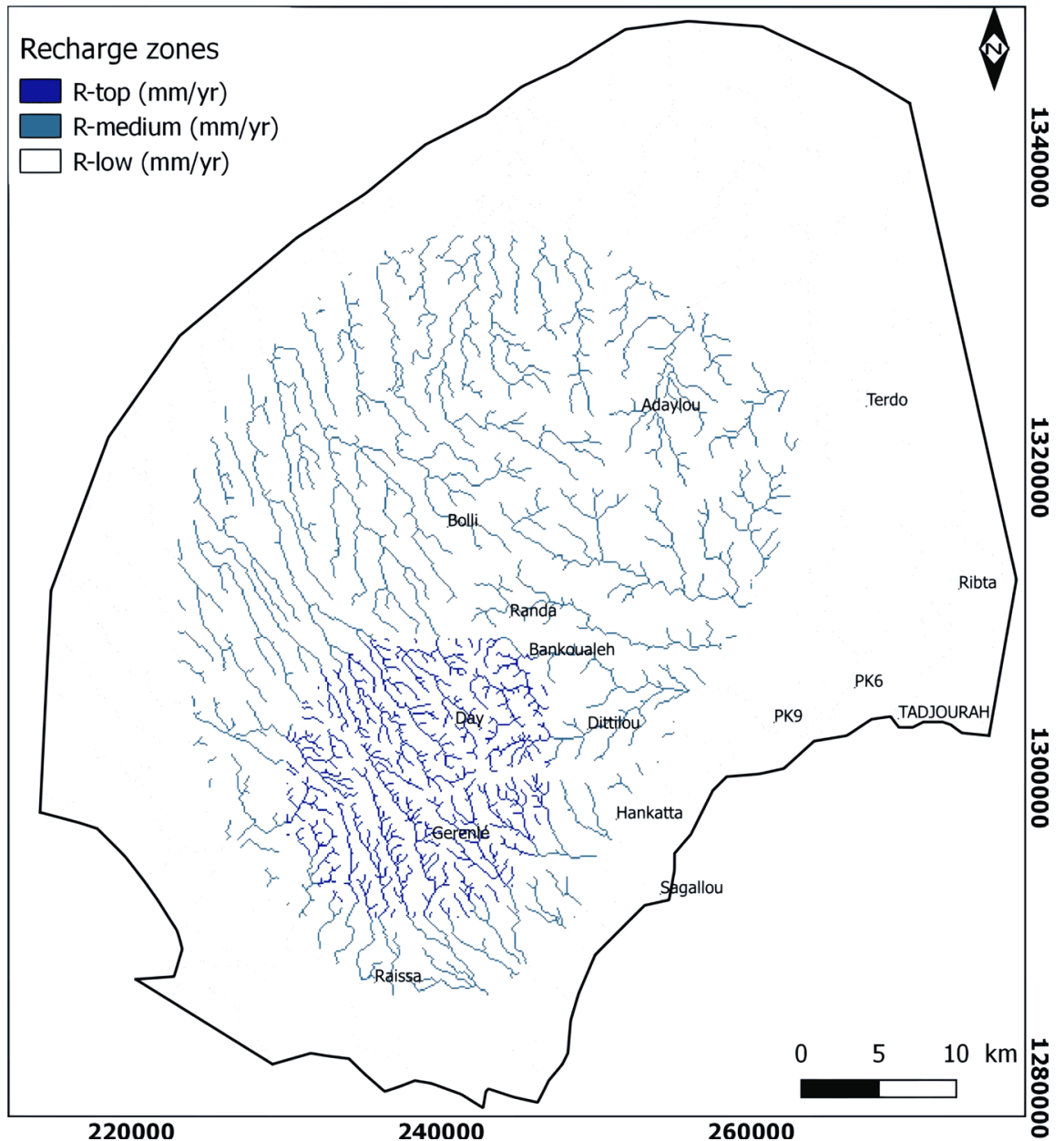

Figure 6. Recharge zones for the second scenario (Indirect recharge).

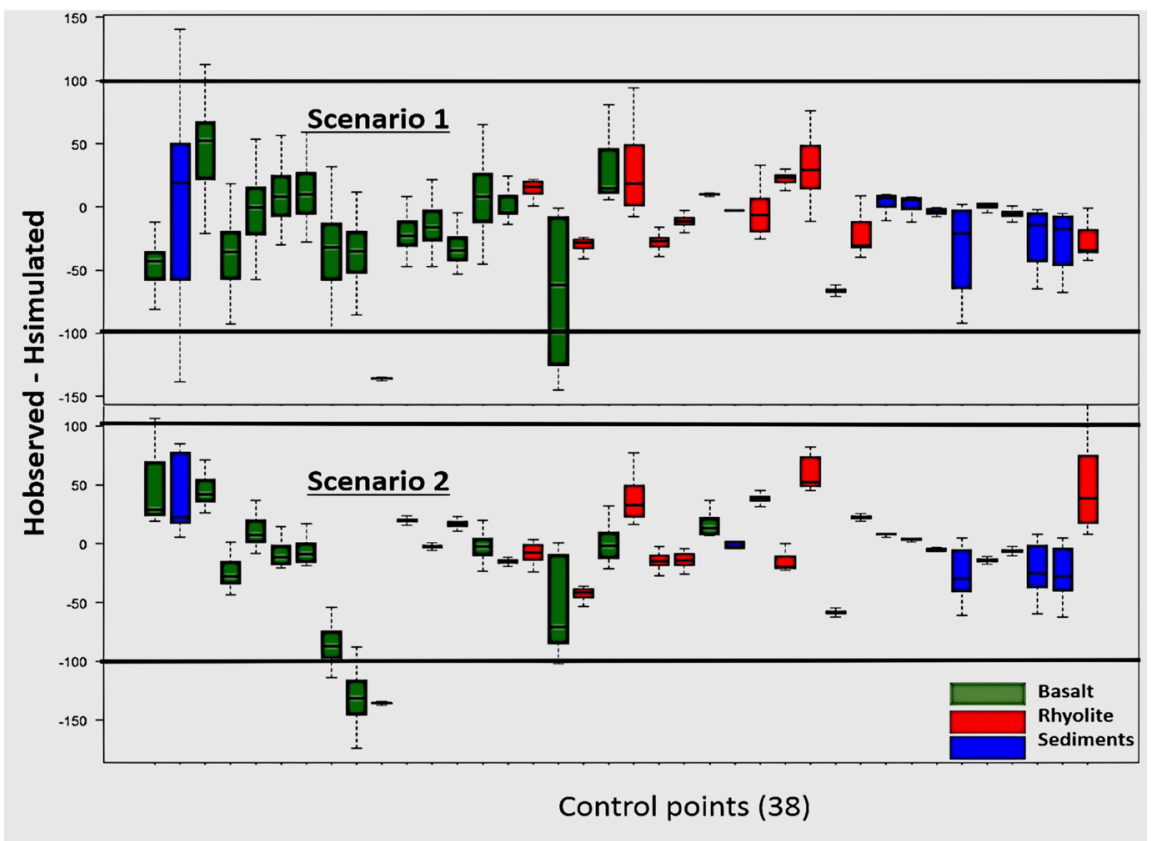

Figure 7. Differences between observed and simulated heads within the first scenario. 

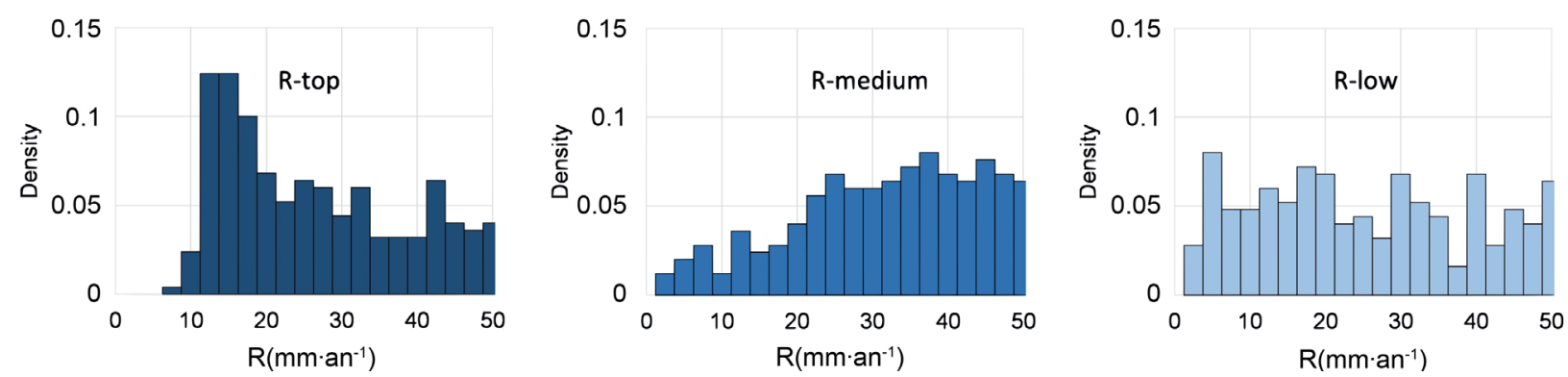

Figure 8. Hydraulic conductivity distribution for the 3 formations within the first scenario.
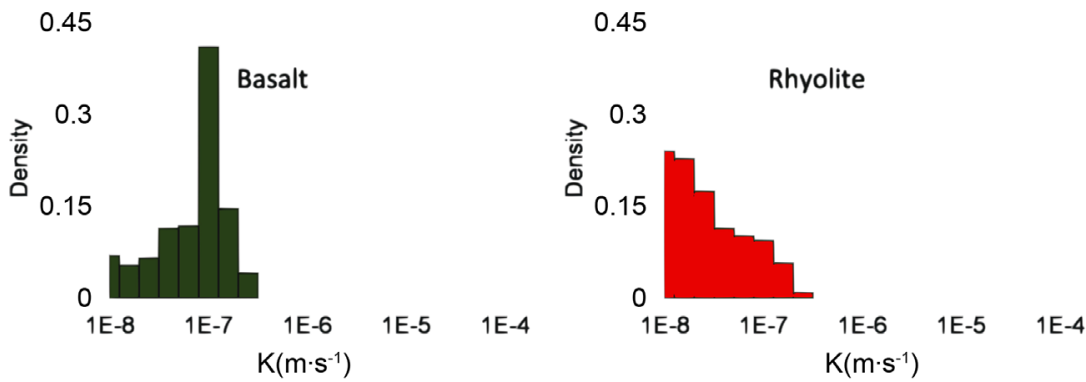

0.45

Figure 9. Recharge distribution for the 3 zones within the first scenario.
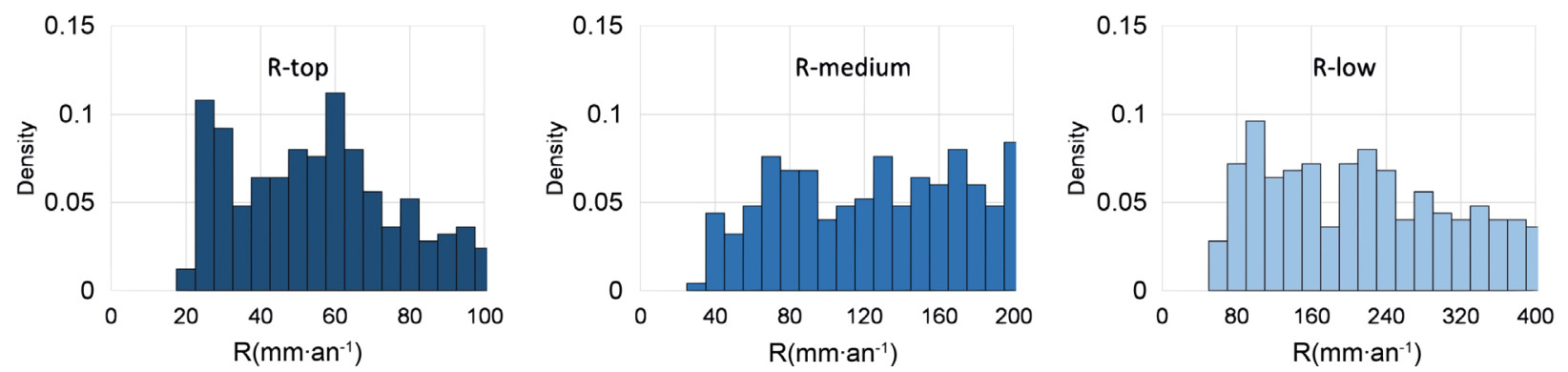

Figure 10. Hydraulic conductivity distribution for the 3 formations within the second scenario.

high. The upper zone receives $52.4 \mathrm{~mm} \cdot \mathrm{y}^{-1}$ and the middle and low zones 123.7 and $198.2 \mathrm{~mm} \cdot \mathrm{mm} \cdot \mathrm{y}^{-1}$ respectively (Figure 11 ).

\section{Discussion}

The probability densities of the hydraulic conductivities of volcanic formations have well-constrained unimodal distributions. The values of hydraulic conductivity obtained for these formations remain on average lower than the values found for the rhyolites. However, for the indirect recharge scenario, the model displays for the basalts a hydraulic conductivity higher than one order of magnitude compared to the modal value obtained for the Mabla rhyolites.

The probability density distributions for sedimentary formations are less constrained and show two subsets of hydraulic conductivity fields for the two recharge configurations. Indeed, according to Jalludin and Razack [3], the hydraulic conductivity of the sedimentary formations presents a great variation due to the difference in the constitutive materials of the alluvial deposits. 

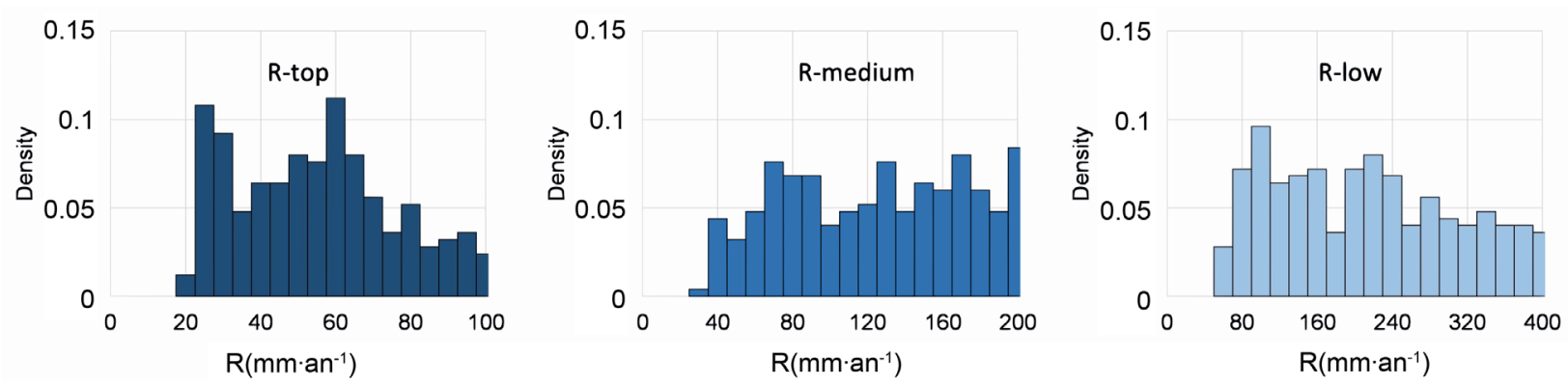

Figure 11. Recharge distribution for the 3 zones within the second scenario.

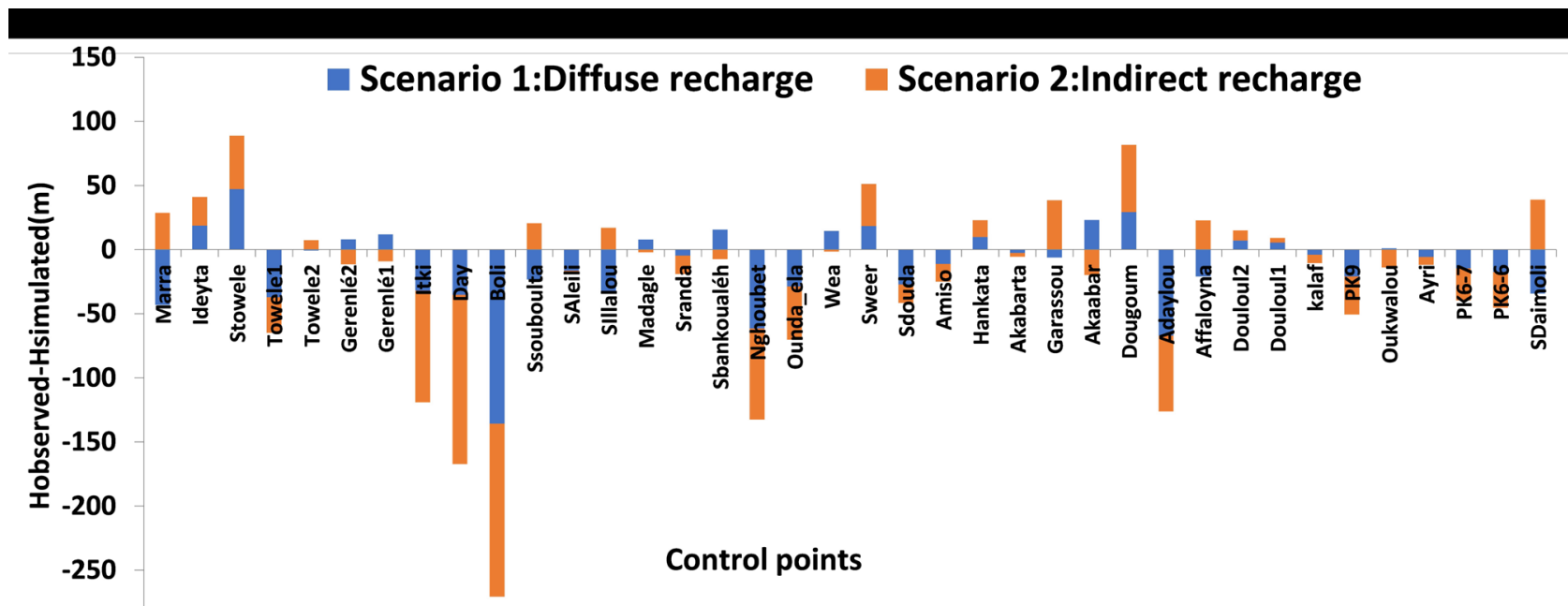

Figure 12. Comparison of the first scenario (diffuse recharge) with the second scenario (indirect recharge).

The only study to estimate recharge, based on field experiments (differential gauges), dates from 1982 and concerns the coastal aquifer of the Gulf basalts [31]. According to this study, this aquifer would receive only $5 \%$ of the annual raw precipitation. The amount of recharge estimated for the different zones depends entirely on the mechanism governing the recharge. Indirect recharge is the dominant mechanism in arid contexts [32] as for Djibouti volcanic aquifers [31] [8], but chemical and isotopic analyzes have shown that aquifers could also benefit of diffuse recharge [33].

Analysis of the different scenarios which have been tested, pointed out that the simulated hydraulic heads are closer to the observed heads in the case of a diffuse recharge scenario (Figure 12). The recharge of the Goda volcanic aquifer, corresponding to this optimal scenario, amounts to $50.8 \times 10^{6} \mathrm{~m}^{3} /$ year representing an average $28 \mathrm{~mm}$ /year over the whole area. This estimation of the recharge is important for the concerned area as it allows a better understanding of the resources that are available and their rational exploitation in the future.

\section{Conclusions}

The classical modeling approaches to estimate the hydrodynamic parameters and the recharge of strongly heterogeneous aquifers rove insufficient in a con- 
text of lack of knowledge and lack of representative data of the studied aquifer system. This is all the more true as the complexity of the concerned aquifer is high.

By testing a wide range of input data (hydraulic conductivity, recharge) for the different main configurations by which the water infiltrates towards deep aquifers, the GLUE approach made it possible to understand that volcanic formations (basalts, rhyolites) have rather low hydraulic conductivity, which order of magnitude is similar for all formations. By cons, the sedimentary formations present significant heterogeneities in hydraulic conductivity probably due to their composition.

The estimated recharge rate varies between $6 \%$ and $12 \%$ of the considered isohyet when diffuse recharge is the dominant mechanism. On the whole, the simulated heads are as close as possible to the observed heads when the precipitation infiltrates diffusely into the aquifer.

This modeling approach has proved to be relevant for a better understanding of the functioning of the complex volcanic system of the Goda rhyolitic massif. An assessment of water resources could be deduced. This result demonstrates the actual performances of the GLUE method in Hydrogeology. This work opens up promising prospects for the modeling of very complex aquifer systems, for which there are very little available data.

\section{References}

[1] Custodio, E. (2007) Groundwater in Volcanic Hard Rocks. In: Groundwater in Fractured Rocks, Taylor \& Francis, Milton Park, 95-108. https://doi.org/10.1201/9780203945650.ch5

[2] Jalludin, M. (1993) Propriétés géométriques et hydrodynamiques des aquifères en milieux volcaniques fissurés sous climat aride : République de Djibouti. Thèse 3ème cycle.Université de Poitiers, 195.

[3] Jalludin, M. and Razack, M. (2004) Assessment of Hydraulic Properties of Sedimentary and Volcanic Aquifer Systems under Arid Conditions in the Republic of Djibouti (Horn of Africa). Hydrogeology Journal, 12, 159-170.

https://doi.org/10.1007/s10040-003-0312-2

[4] Vittecoq, B., Reninger, P.-A., Violette, S., Martelet, G., Dewandel, B. and Audru, J.-C. (2015) Heterogeneity of Hydrodynamic Properties and Groundwater Circulation of a Coastal Andesitic Volcanic Aquifer Controlled by Tectonic Induced Faults and Rock Fracturing-Martinique Island (Lesser Antilles-FWI). Journal of Environmental Hydrology, 529, 1041-1059. https://doi.org/10.1016/j.jhydrol.2015.09.022

[5] Bertrand, G., Celle-Jeanton, H., Huneau, F., Loock, S. and Renac, C. (2010) Identification of Different Groundwater Flow Paths within Volcanic Aquifers Using Natural Tracers for the Evaluation of the Influence of Lava Flows Morphology (Argnat basin, Chaîne des Puys, France). Journal of Hydrology, 391, 223-234. https://doi.org/10.1016/j.jhydrol.2010.07.021

[6] Kahle, S.C. and Vaccaro, J.J. (2015) Groundwater Resources of the Columbia Plateau Regional Aquifer System. U.S. Geological Survey, Reston, VA, 6. https://doi.org/10.3133/fs20153063 
[7] Deolankar, S.B. (1980) The Deccan Basalts of Maharashtra, India-Their Potential as Aquifers. Ground Water, 18, 434-437. https://doi.org/10.1111/j.1745-6584.1980.tb03416.x

[8] Houmed-Gaba, A. (2009) Hydrogéologie des milieux volcaniques sous-climat aride. Caractérisation et modélisation numérique de l'aquifère basaltique de Djibouti (corne de l'Afrique). Thèse 3ème cycle.Université de Poitiers, 220.

[9] Aboubakar, M. (2012) Caractérisation d'un système aquifère volcanique par approche couplée hydrogéochimique et modélisation numérique. Exemple de l'aquifère des basaltes de Dalha, sud-ouest de la République de Djibouti. Thèse 3ème cycle, Université de Poitiers, 220.

[10] Ireson, A., Makropoulos, C. and Maksimovic, C. (2006) Water Resources Modelling under Data Scarcity: Coupling MIKE BASIN and ASM Groundwater Model. Water Resources Management, 20, 567-590. https://doi.org/10.1007/s11269-006-3085-2

[11] Candela, L., Elorza, F.J., Tamoh, K., Jiménez-Martínez, J. and Aureli, A. (2014) Groundwater Modelling with Limited Data Sets: The Chari-Logone Area (Lake Chad Basin, Chad). Hydrological Processes, 28, 3714-3727.

https://doi.org/10.1002/hyp.9901

[12] Yeh, W.-G. (1986) Review of Parameter Identification Procedures in Groundwater Hydrology: The Inverse Problem. Water Resources Research, 22, 95-108. https://doi.org/10.1029/WR022i002p00095

[13] Sun, N.-Z. (1994) Inverse Problems in Groundwater Modeling. Springer Science \& Business Media, Berlin, 346 p.

[14] Hyun, Y. and Lee, K.-K. (1998) Model Identification Criteria for Inverse Estimation of Hydraulic Parameters. Ground Water, 36, 230-239. https://doi.org/10.1111/j.1745-6584.1998.tb01088.x

[15] Barenblatt, G.I., Zheltov, I.P. and Kochina, I.N. (1960) Basic Concepts in the Theory of Seepage of Homogeneous Liquids in Fissured Rocks. Journal of Applied Mathematics and Mechanics, 24, 1286-1303. https://doi.org/10.1016/0021-8928(60)90107-6

[16] Zhou, H., Gómez-Hernández, J.J. and Li, L. (2014) Inverse Methods in Hydrogeology: Evolution and Recent Trends. Advances in Water Resources, 63, 22-37. https://doi.org/10.1016/j.advwatres.2013.10.014

[17] Beven, K. and Binley, A. (2014) GLUE: 20 Years on. Hydrological Processes, 28, 5897-5918. https://doi.org/10.1002/hyp.10082

[18] Christensen, S. (2004) A Synthetic Groundwater Modelling Study of the Accuracy of GLUE Uncertainty Intervals. Hydrology Research, 35, 45-59.

[19] Hassan, A.E., Bekhit, H.M. and Chapman, J.B. (2008) Uncertainty Assessment of a Stochastic Groundwater Flow Model Using GLUE Analysis. Journal of Hydrology, 362, 89-109. https://doi.org/10.1016/j.jhydrol.2008.08.017

[20] Rojas, R., Feyen, L. and Dassargues, A. (2008) Conceptual Model Uncertainty in Groundwater Modeling: Combining Generalized Likelihood Uncertainty Estimation and Bayesian Model Averaging. Water Resources Research, 44, W12418. https://doi.org/10.1029/2008WR006908

[21] Singh, A., Mishra, S. and Ruskauff, G. (2010) Model Averaging Techniques for Quantifying Conceptual Model Uncertainty. Ground Water, 48, 701-715. https://doi.org/10.1111/j.1745-6584.2009.00642.x

[22] Collet, B., Taud, H., Parrot, J.F., Bonavia, F. and Chorowicz, J. (2000) A New Kinematic Approach for the Danakil Block using a Digital Elevation Model Representa- 
tion. Tectonophysics, 316, 343-357.

https://doi.org/10.1016/S0040-1951(99)00263-2

[23] Eagles, G., Gloaguen, R. and Ebinger, C. (2002) Kinematics of the Danakil Microplate. Earth and Planetary Science Letters, 203, 607-620. https://doi.org/10.1016/S0012-821X(02)00916-0

[24] Mckenzie, D.P., Davies, D. and Molnar, P. (1970) Plate Tectonics of the Red Sea and East Africa. Nature, 226, 243-248. https://doi.org/10.1038/226243a0

[25] Mohr, P.A. (1970) The Afar Triple Junction and Sea-Floor Spreading. Journal of Geophysical Research, 75, 7340-7352. https://doi.org/10.1029/JB075i035p07340

[26] Tazieff, H., Varet, J., Barberi, F. and Giglia, G. (1972) Tectonic Significance of the Afar (or Danakil) Depression. Nature, 235, 144-147. https://doi.org/10.1038/235144a0

[27] Gadalia, A. (1980) Les rhyolites du stade initial de l'ouverture d'un rift: Exemple des rhyolites miocènes de l'Afar. Thèse 3ème cycle, Université de Paris-Sud, Orsay, 406 p.

[28] Fournier, M., Gasse, F., Richard, O. and Ruegg, J.C. (1985) Notice Explicative: Carte géologique de la République de Djibouti à 1/100000: Tadjourah. ISERST, Ministère de la coopération Française.

[29] Stietljes, L. (1973) L'axe tectono-volcanique d'Asal (Afar central-Territoire français des Afars et des Issas) (the volcano-tectonic axis of Asal Central of Afar depression, French territory of Afar and Issas). Thèse 3è cycle, Université de Paris-Sud, Orsay, $196 \mathrm{p}$.

[30] Panday, S., Langevin, C.D., Niswonger, R.G., Ibaraki, M. and Hughes, J.D. (2013) MODFLOW-USG Version 1: An Unstructured Grid Version of MODFLOW for Simulating Groundwater Flow and Tightly Coupled Processes using a Control Volume Finite-Difference Formulation. US Geological Survey.

[31] BGR (1982) Inventaire et mise en valeur des ressources en eau de la République de Djibouti. Coopération Hydrogéologique Allemande. Ministère de l'agriculture, République de Djibouti. Bundesanstalt für Geowissenschaften und Rohstoffe (BGR), Hannover.

[32] Scanlon, B.R., et al. (2006) Global Synthesis of Groundwater Recharge in Semiarid and Arid Regions. Hydrological Processes, 20, 3335-3370. https://doi.org/10.1002/hyp.6335

[33] Froehlich, K., Geyh, M.A., Verhagen, B.T. and Wirth, K. (1987) Isotope Hydrology Applied to Evaluation of Groundwater in Arid Areas. Weltforum Verl, 187 p. 